\title{
Drinking motives and alcohol use among college students with the alcohol
}

\section{flush reaction}

Sarah Soyeon $\mathrm{Oh}^{1,2}$, Yeong Jun $\mathrm{Ju}, \mathrm{PhD}^{1,2}$, San Lee, $\mathrm{MD}^{1,3}$, Sung-in Jang, MD, $\mathrm{PhD}^{1,4}$ Eun-Cheol Park, $\mathrm{MD}, \mathrm{PhD}^{1,4}$

1. Institute of Health Services Research, Yonsei University, Seoul, Republic of Korea

2. Department of Public Health, Graduate School, Yonsei University, Seoul, Republic of Korea

3. Department of Psychiatry, Yonsei University College of Medicine, Seoul, Republic of Korea

4. Department of Preventive Medicine, Yonsei University College of Medicine, Seoul, Republic of Korea

* Corresponding author: Eun-Cheol Park, MD, PhD

Department of Preventive Medicine and Institute of Health Services Research, Yonsei University College of Medicine, 50 Yonsei-ro, Seodaemun-gu, Seoul 120-752, Korea

Tel.: +82-2-2228-1862, Fax: +82-2-392-8133

E-mail: ecpark@yuhs.ac

Word count: 4,636 


\begin{abstract}
Background: This study investigated the relationship between drinking motives and alcohol use among a nationally representative sample of college students with the alcohol flush reaction (AFR). We surveyed and analyzed the data of 2,245 male and 2,326 female college students in a nationally representative sample of 82 colleges in South Korea.
\end{abstract}

Methods: Of our study population, 725 males (32.3\%) and 812 females (34.9\%) reported to currently suffering from AFR. Multiple regression analysis was used to identify the association between drinking motives and drinking behavior, measured via the AUDIT.

Results: Relative to drinking because of peer pressure, students drinking for pleasure (males: $\beta=$ 2.622, $p<.0001$; females $\beta=2.769, p<.0001$ ) or stress/depression (males: $\beta=2.479, p<.0001$; females $\beta=2.489, p<.0001$ ) had higher AUDIT scores. Among students drinking because of stress/depression, seniors (males: $\beta=3.603, p<.0001$; females: $\beta=3.791, p=0.000$ ), smokers (males: $\beta=1.564, p=0.000$; females $\beta=1.816, p=0.007$ ) and/or liberal arts students (males: $\beta=6.1136$, $p<.0001$; females $\beta=4.2105, p<.0001)$ consumed more alcohol than their peers. Relative to conformity motives, enhancement and coping motives were found to have a greater influence on alcohol intake among college students with alcohol flush reaction.

Conclusion: Considering that the flush reaction can occur in AFR individuals after just one sip of wine, our results show that educators and policymakers must take action to deal with this problem.

Keywords: Alcohol flush reaction; ALDH2*2; college drinking; drinking motives 


\section{INTRODUCTION}

The alcohol flush reaction (AFR) is a symptom that approximately $36 \%$ of East Asians (Japanese, Chinese, and Koreans) have (Brooks et al., 2009). Also known as the "Asian Glow" or "alcohol-induced facial flushing", individuals with this symptom are likely to experience a reddening of the face, nausea, and increased heart rate upon consuming alcohol (Ma et al., 2017).

AFR occurs when an individual inherits a deficiency in the single nucleotide polymorphism, ALDH2*504lys (ALDH2), which results in accretion of toxic acetaldehydes in the body (Adams and Rans, 2013). For individuals with AFR, toxic acetaldehyde build-up can occur from the first sip of alcohol (Price et al., 2004) which is extremely dangerous as acetaldehyde build-up has been classified as a Group 1 human carcinogen by the International Agency for Research on Cancer of the World Health Organization (Salaspuro, 2011). Low-activity ALDH2 has been uniformly associated with various cancers including esophageal (Brooks et al., 2009, Cui et al., 2009, Gu et al., 2012, Liu et al., 2017, Matsuo et al., 2001, Wu et al., 2013, Yang et al., 2007, Yang et al., 2010, Yu et al., 2018, Zhang et al., 2010), gastric (Chen et al., 2016, Duell et al., 2012, Ghosh et al., 2017, Hidaka et al., 2015, Ishioka et al., 2018, Jiang et al., 2017, Wang et al., 2014, Yang et al., 2017), colorectal (Crous-Bou et al., 2013, Guo et al., 2013, Matsuo et al., 2006, Xinhua and Yanfei, 2017, Yang et al., 2009, Zhao et al., 2016, Zhong et al., 2016), and stomach (Matsuo et al., 2013).

The association between AFR and cancer in the oral cavity and esophagus (squamous cell carcinoma) is particularly alarming as esophageal cancer has one of the lowest 5-year survival rates of all cancers in Korea for both males (35.0\%) and females (37.3\%) (Jung et al., 2017). Researchers have stated that if moderate or heavy drinking ALDH2 heterozygotes decreased their alcohol intake, more than $50 \%$ of esophageal squamous cell carcinomas could be prevented in East Asian populations (Brooks et al., 2009).

Unfortunately, alcohol-induced facial flushing is a research area that has been limitedly researched for a nationally representative sample of South Koreans, despite affecting around 1/3 of the population. This is alarming as 50,100 males and 30,500 females in Korea die from cancer 
annually, and the alcohol consumption (in liters of pure alcohol) per capita (15+) in Korea averages 12.3 liters, which is more than double the Western Pacific Region's average of 5.4 liters. It is also unusual as ALDH2 deficiency is relatively simple for clinicians to determine; because of the intensity of symptoms, most flushers are able to answer to questions that determine ALDH2 deficiency (Brooks et al., 2009).

Furthermore, limited research has been done on what drinking motives influence individuals with alcohol-induced facial flushing to drink. Currently, there is only a consensus among academics that individuals with the reaction are less likely to drink than non-flushers with respect to both frequency and amount (Suwaki and Ohara, 1985, Suzuki et al., 1997). Research indicates that social motives, characterized by positive reinforcement generated externally from drinking alcohol with others, and enhancement motives, generated from the psychoactive effects of consuming alcohol, are the most common motives for alcohol use among university students (Maphisa, 2018 \#8). Thus, given the limited literature on drinking motives among individuals with AFR, two important questions remain: 1. Do the same drinking motives apply to college students, who suffer from the irritating symptoms of AFR? 2. Which drinking motives increase alcohol consumption, and the risk of alcoholrelated problems among individuals with AFR? Therefore, the present study focuses on examining the association between drinking motives and alcohol use among individuals with AFR in South Korea. It also investigates the factors that strengthen or discourage this relationship.

\section{MATERIALS AND METHODS}

\section{Study population and data}

In the 2017 national statistics published by the Korean Educational Development Institute on college students, we found that 1,951,940 students (4-year: 1,506,745; liberal arts: 445,195) are enrolled in 356 colleges (4-year: 195, liberal arts: 161) in South Korea. Thus, we stratified a proportionately representative sample of undergraduate students from 54 4-year colleges and 28 
liberal arts colleges. Students in these colleges were further stratified according to major, sex, and region (Seoul, Incheon/Gyeonggi, Gangwon, Daejeon/Chungjeong, Gwangju/Jeolla, Daegu/Gyeongbuk, Busan/Ulsan/Gyeongnam) to be representative of national statistics. After completion of a small pilot study, we randomly selected 4,571 students from this sample for our questionnaire. Of these students, we extracted the data of those who self-reported to currently suffering from alcohol-induced facial flushing, for a final study population of 725 males and 812 females with AFR.

Data was collected via face-to-face surveys with students. The 14-page survey instrument asked students a number of questions about their drinking behavior, health, and thoughts on campusalcohol policy. Whenever possible, the instrument included alcohol-related questions that had been previously used in other international, national or large-scale epidemiological studies including the Harvard College Alcohol Study (Wechsler et al., 2002), the Korea National Health and Nutrition Examination Survey (KNHANES), and the Korea Youth Risk Behavior Web-Based Survey (KYRBS).

A standard drink was defined as the amount of alcohol contained in one glass of alcohol drink (approximately 8 grams of pure alcohol), equivalent to: 1 shot of soju, 1 glass of bottled beer, $2 / 3$ of a canned beer, 1/2 glass of draft beer, 1/2 bowl of makgeolli (rice wine), 1/2 glass of wine, 1 glass of whiskey, 1 shot of cheongju (refined rice wine), 1 shot of herbal liquor, 1 shot of fruit wine, or a 3/5 glass of mixed liquor (soju+beer), in accordance with the standards of the Korea Centers for Disease Control \& Prevention.

\section{Measures}

\section{Outcome Variable}

In this study, alcohol intake, measured through the Alcohol Use Disorders Identification Test (AUDIT), was selected as the outcome variable. The AUDIT questionnaire was given in its original 
format, consisting of ten questions related to frequency of drinking, number of drinks per session, frequency of heavy drinking, impaired control following drinking, morning-after drinking, and feelings of guilt upon drinking, frequency of blackouts, alcohol-related injuries, and family concern over drinking.

\section{Drinking Motives}

Drinking motives were measured via individual answers to the question, "In the last 12 months, what was your main reason for drinking alcohol?" Answers were categorized into "peer pressure," "pleasure," "stress/depression," "boredom," and "other." 'Other' responses included the following: "force of habit," "birthday," "anniversary," "to sleep."

\section{Statistical analysis}

Frequencies and mean AUDIT scores were calculated for each variable through $t$ tests and analyses of variance. To examine the relationship between reason for alcohol consumption and AUDIT score, multiple logistic regression analysis was performed, after controlling for the following confounders: year level, major, GPA, pocket money, living status, smoking status, stress level, depressive thoughts, suicidal thoughts, suicidal attempt, underage drinking experience, and number of sororities/clubs.

Alcohol-induced facial flushing was measured through the questionnaire created by Yokoyama and Omori, which asks the following questions to determine past and present ALDH2 heterozygotes: 1) Do you have a tendency to develop facial flushing immediately after drinking a glass (about $180 \mathrm{~mL}$ ) of beer? 2) Did you have the tendency in the first one or two years after you started drinking? This questionnaire was rated to have a high sensitivity rate of $90.1 \%$ and specificity rate of $88.0 \%$ (Yokoyama et al., 2010) in classifying respondents into never, former, and current sufferers of ALDH2 deficiency. 
The simultaneous relationship between alcohol use and other factors like year level and amount of pocket money, according to reason for alcohol consumption, were determined by subgroup analyses. The calculated p-values in this study were considered significant if lower than 0.05 . All analyses were performed using SAS software, version 9.4 (SAS Institute, Cary, North Carolina, USA).

\section{RESULTS}

Of the entire study population, the prevalence of alcohol-induced facial flushing was $32.3 \%$ for male students and $34.9 \%$ for female students. Mean AUDIT scores of students with AFR were $8.253 \pm 5.341$ for males and $7.233 \pm 5.474$ for females, whilst non-AFR students had mean AUDIT scores of $10.518 \pm 5.379$ and $10.369 \pm 6.144$, respectively. Relative to never- and past- sufferers of facial flushing, individuals with current facial flushing were less likely to have high AUDIT scores as illustrated in Figure 1.

Table 1 shows the general characteristics of the AFR population. $34.5 \%$ of the male population (n 250) and $31.8 \%$ of the female population (n 258) reported to consuming alcohol because of peer pressure. This was followed by individuals who drink because of pleasure (males: 29.7\%; females: $30.7 \%$ ) or stress/depression (males: $22.5 \%$; females: $22.5 \%$ ). Individuals who consume alcohol because of pleasure had the highest AUDIT scores (males: $9.758 \pm 4.938$; females: $9.012 \pm 5.487)$

Table 2 shows the results of multiple regression analysis performed to investigate the relationship between various factors and AUDIT score among college students with alcohol-induced facial flushing. Certain drinking motives had a statistically significant association with increased alcohol intake: relative to drinking because of peer pressure, students drinking for pleasure (males: $\beta$ $=2.622, p<.0001$; females $\beta=2.769, p<.0001$ ) or stress/depression (males: $\beta=2.479, p<.0001$; females $\beta=2.489, p<.0001$ ) had higher AUDIT scores. Whilst year level had no statistically 
significant association with alcohol intake for male flushers, female flushers in their senior year or above scored lower on the AUDIT than those in their freshman year $(\beta=-1.587, p=0.002)$. Students receiving higher amounts of pocket money were likely to drink more than students with lower levels of income (males: $\beta=1.093, p=0.039$; females $\beta=12.739, p<.0001$ ). For both males and females, relative to non-smokers, past (males: $\beta=1.994, p=0.003$; females $\beta=5.090, p<.0001$ ) and current smokers (males: $\beta=1.564, p=0.000$; females $\beta=1.816, p=0.007$ ) were likely to score higher on the AUDIT, as well as females with underage drinking experience $(\beta=0.714, p=0.042)$ compared to those without such experience. For both males and females, those in two or more sororities/clubs had higher levels of alcohol intake than those in no sororities/clubs (males: $\beta=1.383, p=0.030$; females $\beta=1.156, p=0.052)$.

Figure 2 shows the results of the subgroup analysis for the association between reason for alcohol consumption and AUDIT scores by year level, major, and amount of pocket money. Regarding year level, for male flushers, alcohol intake was highest among freshmen consuming alcohol because of stress/depression $(\beta=4.213, p<.0001)$ and seniors consuming alcohol for pleasure $(\beta=3.603, p<.0001)$. For female flushers, alcohol intake was highest among sophomores $(\beta=4.101$, $p<.0001)$ and seniors $(\beta=3.791, p=0.000)$ consuming alcohol for pleasure. Regarding major, for both sexes, alcohol intake was highest among liberal arts students consuming alcohol because of stress/depression (males: $\beta=6.1136, p<.0001$; females $\beta=4.2105, p<.0001$ ). Lastly, female students receiving high amounts of pocket money were likely to consume large amounts of alcohol for both pleasure $(\beta=5.454, p<.0001)$ and stress/depression-related $(\beta=5.833, p=0.000)$ purposes, relative to students with low levels of pocket money.

\section{DISCUSSION}

In individuals with AFR, the flush-reaction can begin to occur after just one sip of wine (Price et al., 2004). Such individuals, who have an inability to metabolize the substance, should not be encouraged to consume any alcohol. However, our study shows that individuals with AFR, especially 
those who drink for pleasure or to alleviate stress/depression drink above this level. As seen in Table 1, the mean AUDIT score for flushers in our study population was $8.253 \pm 5.341$ for males and 7.233 \pm 5.474 for females. This is above the AUDIT cut-off for hazardous drinking among normal populations without AFR of 10 (males) and 5 (females) (male cut-off: sensitivity, 81.90\%; specificity, $81.33 \%$; positive predictive value, $77.2 \%$; negative predictive value, $85.3 \%$; female cut-off sensitivity, $100.00 \%$; specificity, $88.54 \%$; positive predictive value, $52.6 \%$; negative predictive value, $100.0 \%$ ) (Chang et al., 2016). Female students with AFR especially, drink well-above this cut-off level, especially if their drinking motive is 'pleasure,' 'stress/depression,' or 'boredom.'

Furthermore, our study reveals what the existing body of literature has failed or refused to acknowledge: individuals with AFR often enjoy alcohol consumption and this is both hazardous and dangerous for their health. Because of the irritating symptoms of AFR, acetaldehyde dehydrogenase inhibition has been used by drug-makers to develop effective treatments for alcoholics (Brewer et al., 2017, Ulrichsen et al., 2010). However, these symptoms have clearly not been powerful enough to prevent the hazardous drinking of around $30 \%$ of AFR individuals in our study population, who find drinking pleasurable.

Lastly, our research shows that the drinking motives behind college students with AFR slightly differ from the drinking motives of college students without AFR. The existing body of research states that social and enhancement motives are the most frequently endorsed by university students, whilst coping motives are found to be most strongly associated with negative alcohol consequences (Merrill, $2010 \# 10$ ). However, our study reveals that among college students with AFR, enhancement motives like pleasure, are the strongest drinking motive and most likely to cause risk of Alcohol Use Disorder, followed closely by coping motives like stress/depression.

This study has several limitations that should be considered when interpreting results. First, our study is cross-sectional in design; thus, caution should be exercised in interpreting causality between reason for alcohol consumption and alcohol intake. Furthermore, the Yokoyama and Omori questionnaire for determining ALDH2 deficiency, as well as the AUDIT cut-off values set by Chang, 
are limited in reliability and validity relative to clinical evaluations of these symptoms by a healthcare professional.

Second, there are not enough previous studies with regard to a nationally representative population of Koreans when it comes to measuring alcohol-induced facial flushing and its effect on drinking behavior/related problems. It is difficult to see whether the values we calculated are similar to that of the statistics found in previous studies for Koreans, especially for the college students' age group. Third, various biases may have emerged from our sampling and surveying methods; because college students in South Korea drink large amounts of alcohol relative to adults, different patterns are likely to emerge in an adult sample. Likewise, a small number of Christian colleges that were originally in our sample declined our request for participation because of their teetotalism principles and thus, had to be replaced with non-Christian colleges. Because of the face-to-face method that we employed for accuracy of obtaining responses to complicated questions, there may have been response biases, relative to social desirability. The majority of questions in our survey instrument required students to think about their drinking behaviors in the last 12 months or so, which likely resulted in recall bias. Finally, although we included numerous lifestyle covariates as potential confounders, the limited nature and number of questions in our instrument made it difficult for other confounding variables, relative to health, socio-demographics, gene-environment, and lifestyle, to be measured and controlled.

Despite these limitations, our study also has several strengths. Few studies have measured ALDH2 deficiency for a nationally representative population in South Korea, and fewer studies have taken an epidemiological approach to see the association between ALDH2 deficiency and relative change in drinking behavior, especially with regard to the reasons that encourage individuals with AFR to drink, despite its irritating symptoms. Our study has found certain risk-groups in the college population that overly drink despite suffering from the flush reaction. Researchers, educators, and policy-makers are encouraged to further investigate, and target such students when creating and influencing campus alcohol policy. 
bioRxiv preprint doi: https://doi.org/10.1101/436469; this version posted October 5, 2018. The copyright holder for this preprint (which was not certified by peer review) is the author/funder, who has granted bioRxiv a license to display the preprint in perpetuity. It is made available under aCC-BY 4.0 International license. 
bioRxiv preprint doi: https://doi org/10.1101/436469; this version posted October 5, 2018. The copyright holder for this preprint (which was

not certified by peer review) is the author/funder, who has granted bioRxiv a license to display the preprint in perpetuity. It is made available under aCC-BY 4.0 International license.

Table 1. General characteristics of ARF individuals and AUDIT scores

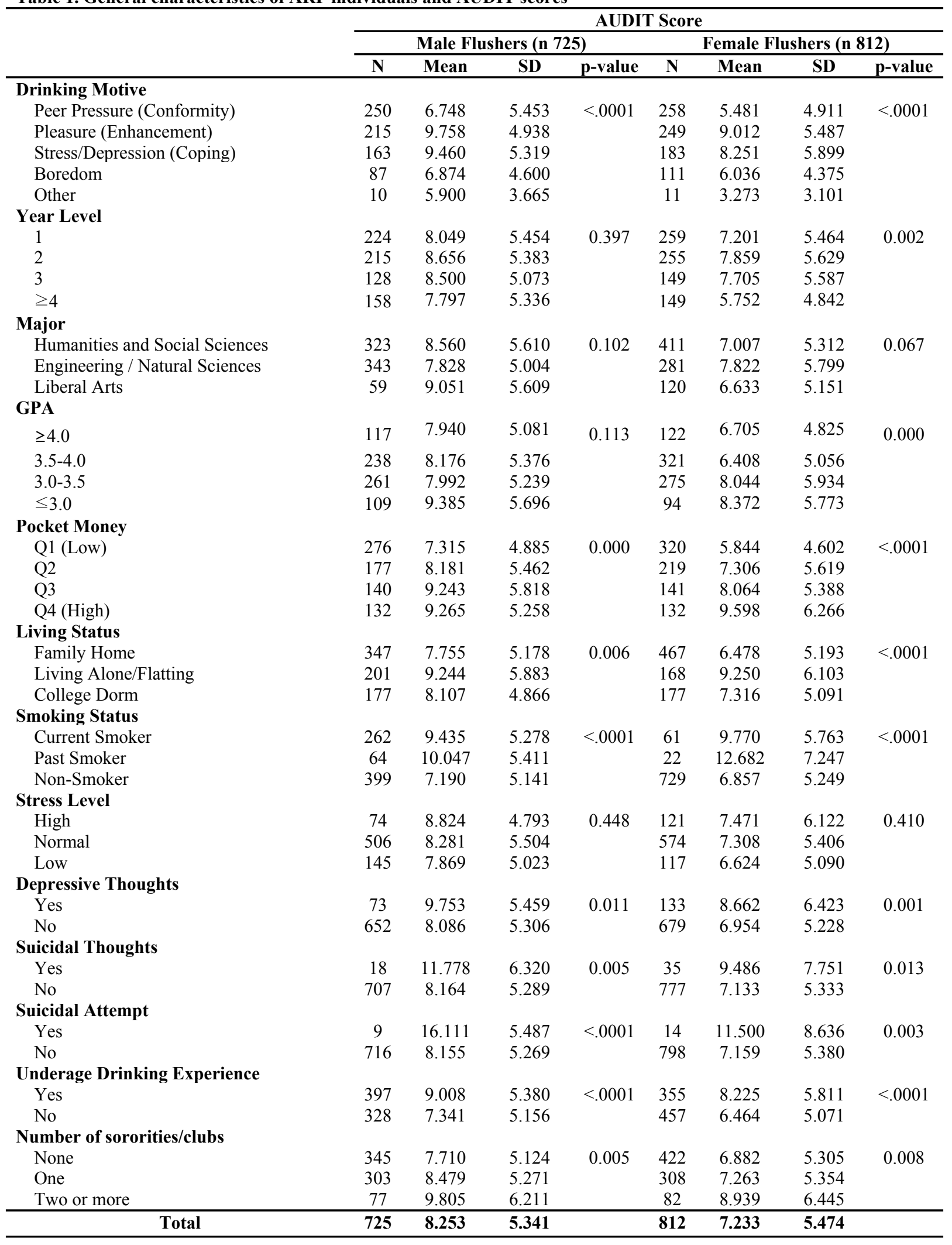


bioRxiv preprint doi: https://doi org/10.1101/436469; this version posted October 5, 2018. The copyright holder for this preprint (which was

not certified by peer review) is the author/funder, who has granted bioRxiv a license to display the preprint in perpetuity. It is made available under aCC-BY 4.0 International license.

Table 2. Results of the GEE analyzing Reason for Alcohol Consumption and AUDIT of ARF individuals

\begin{tabular}{|c|c|c|c|c|c|c|}
\hline & \multicolumn{6}{|c|}{ AUDIT Score } \\
\hline & \multicolumn{3}{|c|}{ Male Flushers } & \multicolumn{3}{|c|}{ Female Flushers } \\
\hline & $\beta^{*}$ & S.E & p-value & $\beta^{*}$ & S.E & p-value \\
\hline \multicolumn{7}{|l|}{ Drinking Motive } \\
\hline Peer Pressure & Ref. & & & & & \\
\hline Pleasure & 2.622 & 0.460 & $<.0001$ & 2.769 & 0.437 & $<.0001$ \\
\hline Stress/Depression & 2.479 & 0.503 & $<.0001$ & 2.489 & 0.475 & $<.0001$ \\
\hline Boredom & -0.261 & 0.607 & 0.667 & 0.469 & 0.551 & 0.394 \\
\hline Other & -0.785 & 1.565 & 0.616 & -2.031 & 1.479 & 0.170 \\
\hline \multicolumn{7}{|l|}{ Year Level } \\
\hline 1 & Ref. & & & Ref. & & \\
\hline 2 & 0.735 & 0.468 & 0.116 & 0.344 & 0.427 & 0.420 \\
\hline 3 & 0.042 & 0.556 & 0.940 & 0.065 & 0.503 & 0.898 \\
\hline$\geq 4$ & -0.425 & 0.526 & 0.419 & -1.587 & 0.508 & 0.002 \\
\hline \multicolumn{7}{|l|}{ Major } \\
\hline Humanities and Social Sciences & Ref. & & & Ref. & & \\
\hline Engineering / Natural Sciences & -0.421 & 0.383 & 0.272 & 0.512 & 0.375 & 0.173 \\
\hline Liberal Arts & 0.341 & 0.692 & 0.622 & -0.472 & 0.509 & 0.354 \\
\hline \multicolumn{7}{|l|}{ GPA } \\
\hline$\geq 4.0$ & Ref. & & & Ref. & & \\
\hline $3.5-4.0$ & -0.121 & 0.555 & 0.827 & 0.014 & 0.519 & 0.978 \\
\hline $3.0-3.5$ & -0.003 & 0.541 & 0.996 & 1.334 & 0.528 & 0.012 \\
\hline$\leq 3.0$ & 1.334 & 0.654 & 0.042 & 0.805 & 0.666 & 0.227 \\
\hline \multicolumn{7}{|l|}{ Pocket Money } \\
\hline Q1 (Low) & Ref. & & & Ref. & & \\
\hline Q2 & 0.485 & 0.473 & 0.305 & 1.161 & 0.429 & 0.007 \\
\hline Q3 & 1.358 & 0.522 & 0.009 & 1.874 & 0.493 & 0.000 \\
\hline Q4 (High) & 1.093 & 0.530 & 0.039 & 2.739 & 0.514 & $<.0001$ \\
\hline \multicolumn{7}{|l|}{ Living Status } \\
\hline Family Home & Ref. & & & Ref. & & \\
\hline Living Alone/Flatting & 0.842 & 0.445 & 0.059 & 1.635 & 0.446 & 0.000 \\
\hline \multicolumn{7}{|l|}{ College Dorm } \\
\hline \multicolumn{7}{|l|}{ Smoking Status } \\
\hline Current Smoker & 1.564 & 0.407 & 0.000 & 1.816 & 0.667 & 0.007 \\
\hline Past Smoker & 1.994 & 0.670 & 0.003 & 5.090 & 1.056 & $<.0001$ \\
\hline Non-Smoker & Ref. & & & Ref. & & \\
\hline \multicolumn{7}{|l|}{ Stress Level } \\
\hline High & 0.463 & 0.736 & 0.529 & -0.876 & 0.685 & 0.201 \\
\hline Normal & 0.227 & 0.464 & 0.625 & 0.110 & 0.494 & 0.824 \\
\hline Low & Ref. & & & Ref. & & \\
\hline \multicolumn{7}{|l|}{ Depressive Thoughts } \\
\hline Yes & 0.521 & 0.646 & 0.419 & 0.347 & 0.524 & 0.508 \\
\hline No & Ref. & & & Ref. & & \\
\hline \multicolumn{7}{|l|}{ Suicidal Thoughts } \\
\hline Yes & 1.632 & 1.236 & 0.186 & 0.164 & 1.026 & 0.873 \\
\hline No & Ref. & & & Ref. & & \\
\hline \multicolumn{7}{|l|}{ Suicidal Attempt } \\
\hline Yes & 6.057 & 1.700 & 0.000 & 3.241 & 1.495 & 0.030 \\
\hline No & Ref. & & & Ref. & & \\
\hline \multicolumn{7}{|l|}{ Underage Drinking Experience } \\
\hline Yes & 0.645 & 0.378 & 0.088 & 0.714 & 0.351 & 0.042 \\
\hline No & Ref. & & & Ref. & & \\
\hline \multicolumn{7}{|l|}{ Number of sororities/clubs } \\
\hline None & Ref. & & & Ref. & & \\
\hline One & 0.460 & 0.392 & 0.240 & 0.255 & 0.369 & 0.489 \\
\hline Two or more & 1.383 & 0.637 & 0.030 & 1.156 & 0.594 & 0.052 \\
\hline
\end{tabular}




\section{References}

ADAMS, K. E. \& RANS, T. S. 2013. Adverse reactions to alcohol and alcoholic beverages. Ann Allergy Asthma Immunol, 111, 439-45.

BREWER, C., STREEL, E. \& SKINNER, M. 2017. Supervised Disulfiram's Superior Effectiveness in Alcoholism Treatment: Ethical, Methodological, and Psychological Aspects. Alcohol and Alcoholism, 52, 213-219.

BROOKS, P. J., ENOCH, M. A., GOLDMAN, D., LI, T. K. \& YOKOYAMA, A. 2009. The alcohol flushing response: an unrecognized risk factor for esophageal cancer from alcohol consumption. PLoS Med, 6, e50.

CHANG, J. W., KIM, J. S., JUNG, J. G., KIM, S. S., YOON, S. J. \& JANG, H. S. 2016. Validity of Alcohol Use Disorder Identification Test-Korean Revised Version for Screening Alcohol Use Disorder according to Diagnostic and Statistical Manual of Mental Disorders, Fifth Edition Criteria. Korean Journal of Family Medicine, 37, 323-328.

CHEN, Z. H., XIAN, J. F. \& LUO, L. P. 2016. Analysis of ADH1B Arg47His, ALDH2 Glu487Lys, and CYP4502E1 polymorphisms in gastric cancer risk and interaction with environmental factors. Genet Mol Res, 15.

CROUS-BOU, M., RENNERT, G., CUADRAS, D., SALAZAR, R., CORDERO, D., SALTZ RENNERT, H., LEJBKOWICZ, F., KOPELOVICH, L., MONROE LIPKIN, S., BERNARD GRUBER, S. \& MORENO, V. 2013. Polymorphisms in alcohol metabolism genes ADH1B and ALDH2, alcohol consumption and colorectal cancer. PLoS One, 8, e80158.

CUI, R., KAMATANI, Y., TAKAHASHI, A., USAMI, M., HOSONO, N., KAWAGUCHI, T., TSUNODA, T., KAMATANI, N., KUBO, M., NAKAMURA, Y. \& MATSUDA, K. 2009. Functional variants in ADH1B and ALDH2 coupled with alcohol and smoking synergistically enhance esophageal cancer risk. Gastroenterology, 137, 1768-75.

DUELL, E. J., SALA, N., TRAVIER, N., MUNOZ, X., BOUTRON-RUAULT, M. C., CLAVEL-CHAPELON, F., BARRICARTE, A., ARRIOLA, L., NAVARRO, C., SANCHEZ-CANTALEJO, E., QUIROS, J. R., KROGH, V., VINEIS, P., MATTIELLO, A., TUMINO, R., KHAW, K. T., WAREHAM, N., ALLEN, N. E., PEETERS, P. H., NUMANS, M. E., BUENO-DE-MESQUITA, H. B., VAN OIJEN, M. G., BAMIA, C., BENETOU, V., TRICHOPOULOS, D., CANZIAN, F., KAAKS, R., BOEING, H., BERGMANN, M. M., LUND, E., EHRNSTROM, R., JOHANSEN, D., HALLMANS, G., STENLING, R., TJONNELAND, A., OVERVAD, K., OSTERGAARD, J. N., FERRARI, P., FEDIRKO, V., JENAB, M., NESI, G., RIBOLI, E. \& GONZALEZ, C. A. 2012. Genetic variation in alcohol dehydrogenase (ADH1A, ADH1B, ADH1C, ADH7) and aldehyde dehydrogenase (ALDH2), alcohol consumption and gastric cancer risk in the European Prospective Investigation into Cancer and Nutrition (EPIC) cohort. Carcinogenesis, 33, 361-7.

GHOSH, S., BANKURA, B., GHOSH, S., SAHA, M. L., PATTANAYAK, A. K., GHATAK, S., GUHA, M., NACHIMUTHU, S. K., PANDA, C. K., MAJI, S., CHAKRABORTY, S., MAITY, B. \& DAS, M. 2017. Polymorphisms in ADH1B and ALDH2 genes associated with the increased risk of gastric cancer in West Bengal, India. BMC Cancer, 17, 782.

GU, H., GONG, D., DING, G., ZHANG, W., LIU, C., JIANG, P., CHEN, S. \& CHEN, Y. 2012. A variant allele of ADH1B and ALDH2, is associated with the risk of 
esophageal cancer. Exp Ther Med, 4, 135-140.

GUO, X. F., WANG, J., YU, S. J., SONG, J., JI, M. Y., ZHANG, J. X., CAO, Z., WANG, J. \& DONG, W. G. 2013. Meta-analysis of the ADH1B and ALDH2 polymorphisms and the risk of colorectal cancer in East Asians. Intern Med, 52, 2693-9.

HIDAKA, A., SASAZUKI, S., MATSUO, K., ITO, H., SAWADA, N., SHIMAZU, T., YAMAJI, T., IWASAKI, M., INOUE, M., TSUGANE, S. \& GROUP, J. S. 2015. Genetic polymorphisms of ADH1B, ADH1C and ALDH2, alcohol consumption, and the risk of gastric cancer: the Japan Public Health Center-based prospective study. Carcinogenesis, 36, 223-31.

ISHIOKA, K., MASAOKA, H., ITO, H., OZE, I., ITO, S., TAJIKA, M., SHIMIZU, Y., NIWA, Y., NAKAMURA, S. \& MATSUO, K. 2018. Association between ALDH2 and ADH1B polymorphisms, alcohol drinking and gastric cancer: a replication and mediation analysis. Gastric Cancer.

JIANG, Y., ZHANG, J., WU, Y., WANG, J. \& LI, L. 2017. Association between ALDH2 rs671 G>A polymorphism and gastric cancer susceptibility in Eastern Asia. Oncotarget, 8, 102401-102412.

JUNG, K. W., WON, Y. J., OH, C. M., KONG, H. J., LEE, D. H., LEE, K. H. \& COMMUNITY OF POPULATION-BASED REGIONAL CANCER, R. 2017. Cancer Statistics in Korea: Incidence, Mortality, Survival, and Prevalence in 2014. Cancer Res Treat, 49, 292-305.

LIU, K., SONG, G., ZHU, X., YANG, X., SHEN, Y., WANG, W., SHI, G., LI, Q., DUAN, Y., ZHAO, Y. \& FENG, G. 2017. Association between ALDH2 Glu487Lys polymorphism and the risk of esophageal cancer. Medicine (Baltimore), 96, e6111.

MA, C., YU, B. X. \& ZENG, Q. 2017. Associations between aldehyde dehydrogenase 2 (ALDH2) rs671 genetic polymorphisms, lifestyles and diabetes risk in Chinese Han people. Journal of the American College of Cardiology, 70, C82-C82.

MATSUO, K., HAMAJIMA, N., SHINODA, M., HATOOKA, S., INOUE, M., TAKEZAKI, T. \& TAJIMA, K. 2001. Gene-environment interaction between an aldehyde dehydrogenase-2 (ALDH2) polymorphism and alcohol consumption for the risk of esophageal cancer. Carcinogenesis, 22, 913-6.

MATSUO, K., OZE, I., HOSONO, S., ITO, H., WATANABE, M., ISHIOKA, K., ITO, S., TAJIKA, M., YATABE, Y., NIWA, Y., YAMAO, K., NAKAMURA, S., TAJIMA, K. \& TANAKA, H. 2013. The aldehyde dehydrogenase 2 (ALDH2) Glu504Lys polymorphism interacts with alcohol drinking in the risk of stomach cancer. Carcinogenesis, 34, 1510-5.

MATSUO, K., WAKAI, K., HIROSE, K., ITO, H., SAITO, T., SUZUKI, T., KATO, T., HIRAI, T., KANEMITSU, Y., HAMAJIMA, H. \& TAJIMA, K. 2006. A gene-gene interaction between ALDH2 Glu487Lys and ADH2 His47Arg polymorphisms regarding the risk of colorectal cancer in Japan. Carcinogenesis, 27, 1018-23.

PRICE, R. K., LOBOS, E., RISK, N. \& TODD, R. D. 2004. ALDH2, Alcohol Sensitivity, Ethnicity and Acculturation: A Pilot Study of the Japanese and Vietnamese in St Louis. Unpublished Presentation. Washington School of Medicine.

SALASPURO, M. 2011. Acetaldehyde and gastric cancer. J Dig Dis, 12, 51-9.

SUWAKI, H. \& OHARA, H. 1985. Alcohol-induced facial flushing and drinking behavior in Japanese men. J Stud Alcohol, 46, 196-8.

SUZUKI, K., MATSUSHITA, S. \& ISHII, T. 1997. Relationship between the flushing response and drinking behavior among Japanese high school students. Alcohol Clin Exp Res, 21, 1726-9.

ULRICHSEN, J., NIELSEN, M. K. \& ULRICHSEN, M. 2010. Disulfiram in severe 
alcoholism-an open controlled study. Nordic Journal of Psychiatry, 64, 356-362.

WANG, H. L., ZHOU, P. Y., LIU, P. \& ZHANG, Y. 2014. ALDH2 and ADH1 genetic polymorphisms may contribute to the risk of gastric cancer: a meta-analysis. PLoS One, 9, e88779.

WECHSLER, H., LEE, J. E., NELSON, T. F. \& KUO, M. 2002. Underage college students' drinking behavior, access to alcohol, and the influence of deterrence policies: Findings from the Harvard School of Public Health College Alcohol Study. (vol 50, pg 223, 2002). Journal of American College Health, 51, 37-37.

WU, M., CHANG, S. C., KAMPMAN, E., YANG, J., WANG, X. S., GU, X. P., HAN, R. Q., LIU, A. M., WALLAR, G., ZHOU, J. Y., KOK, F. J., ZHAO, J. K. \& ZHANG, Z. F. 2013. Single nucleotide polymorphisms of ADH1B, ADH1C and ALDH2 genes and esophageal cancer: a population-based case-control study in China. Int J Cancer, $132,1868-77$.

XINHUA, J. \& YANFEI, Z. 2017. Association between ALDH2 Glu504Lys polymorphism and colorectal cancer risk: a meta-analysis. Afr Health Sci, 17, 108-115.

YANG, H., ZHOU, Y., ZHOU, Z., LIU, J., YUAN, X., MATSUO, K., TAKEZAKI, T., TAJIMA, K. \& CAO, J. 2009. A novel polymorphism rs1329149 of CYP2E1 and a known polymorphism rs671 of ALDH2 of alcohol metabolizing enzymes are associated with colorectal cancer in a southwestern Chinese population. Cancer Epidemiol Biomarkers Prev, 18, 2522-7.

YANG, S., LEE, J., CHOI, I. J., KIM, Y. W., RYU, K. W., SUNG, J. \& KIM, J. 2017. Effects of alcohol consumption, ALDH2 rs671 polymorphism, and Helicobacter pylori infection on the gastric cancer risk in a Korean population. Oncotarget, 8, 6630-6641.

YANG, S. J., WANG, H. Y., LI, X. Q., DU, H. Z., ZHENG, C. J., CHEN, H. G., MU, X. Y. \& YANG, C. X. 2007. Genetic polymorphisms of ADH2 and ALDH2 association with esophageal cancer risk in southwest China. World J Gastroenterol, 13, 5760-4.

YANG, S. J., YOKOYAMA, A., YOKOYAMA, T., HUANG, Y. C., WU, S. Y., SHAO, Y., NIU, J., WANG, J., LIU, Y., ZHOU, X. Q. \& YANG, C. X. 2010. Relationship between genetic polymorphisms of ALDH2 and ADH1B and esophageal cancer risk: a meta-analysis. World $J$ Gastroenterol, 16, 4210-20.

YOKOYAMA, A., YOKOYAMA, T. \& OMORI, T. 2010. Past and current tendency for facial flushing after a small dose of alcohol is a marker for increased risk of upper aerodigestive tract cancer in Japanese drinkers. Cancer Science, 101, 2497-2498.

YU, C., GUO, Y., BIAN, Z., YANG, L., MILLWOOD, I. Y., WALTERS, R. G., CHEN, Y., CHEN, Y., ZHANG, X., LEI, Y., CHEN, J., CHEN, Z., LV, J., LI, L. \& CHINA KADOORIE BIOBANK COLLABORATIVE, G. 2018. Association of low-activity ALDH2 and alcohol consumption with risk of esophageal cancer in Chinese adults: A population-based cohort study. Int J Cancer.

ZHANG, G. H., MAI, R. Q. \& HUANG, B. 2010. Meta-analysis of ADH1B and ALDH2 polymorphisms and esophageal cancer risk in China. World J Gastroenterol, 16, 6020-5.

ZHAO, S., DU, X. M., MA, S. S. \& WANG, L. M. 2016. Association between aldehyde dehydrogenase 2 (ALDH2) Glu504Lys polymorphism and susceptibility to colorectal cancer: a meta-analysis. Genet Mol Res, 15.

ZHONG, Q., WU, R. R. \& ZENG, Z. M. 2016. Association of ADH1B Arg47His and ALDH2 Glu487Lys polymorphisms with risk of colorectal cancer and their interaction with environmental factors in a Chinese population. Genet Mol Res, 15. 
bioRxiv preprint doi: https://doi org/10.1101/436469; this version posted October 5, 2018. The copyright holder for this preprint (which was

not certified by peer review) is the author/funder, who has granted bioRxiv a license to display the preprint in perpetuity. It is made available under aCC-BY 4.0 International license.

Table 1. General characteristics of ARF individuals and AUDIT scores

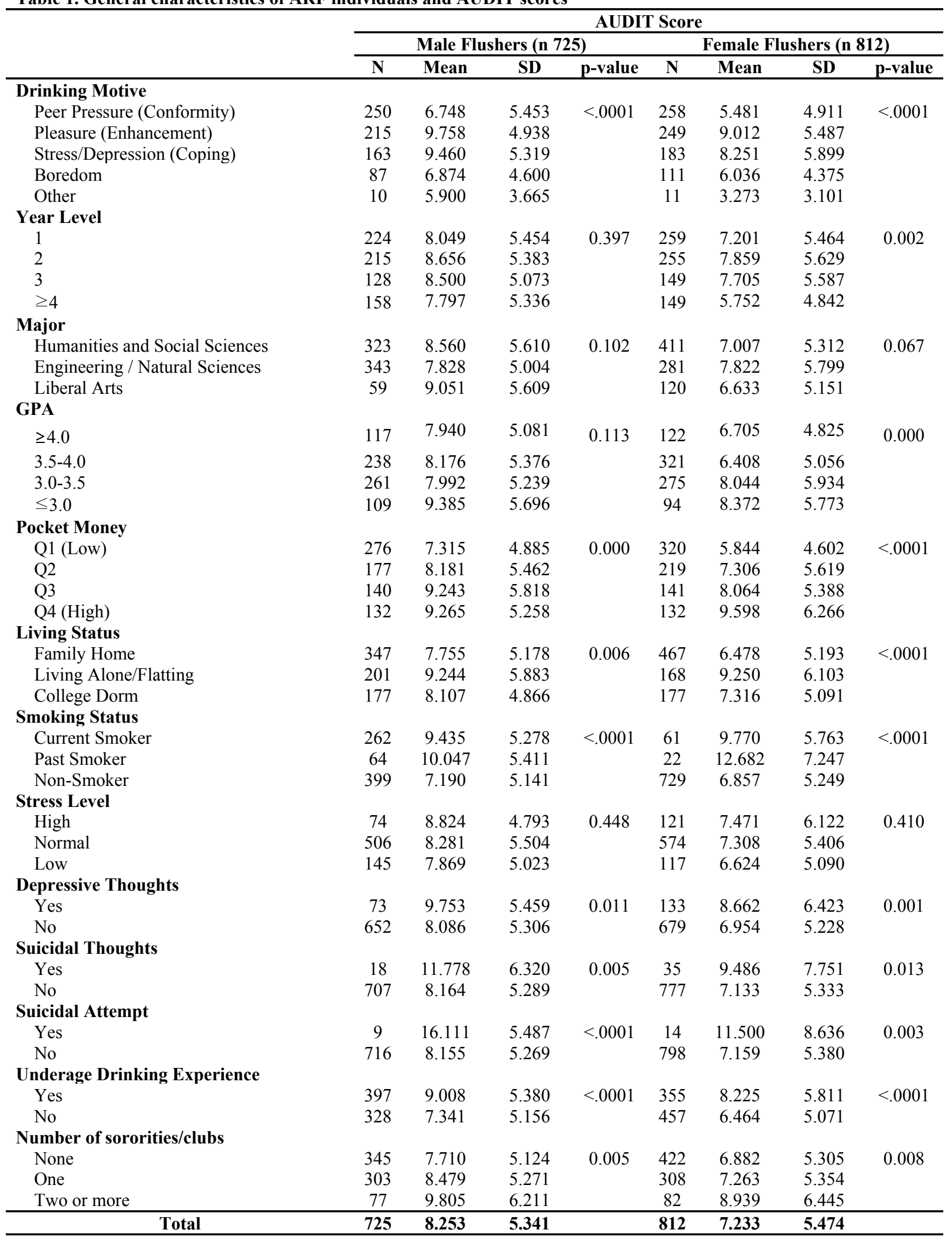


bioRxiv preprint doi: https://doi org/10.1101/436469; this version posted October 5, 2018. The copyright holder for this preprint (which was

not certified by peer review) is the author/funder, who has granted bioRxiv a license to display the preprint in perpetuity. It is made available under aCC-BY 4.0 International license.

Table 2. Results of the GEE analyzing Reason for Alcohol Consumption and AUDIT of ARF individuals

\begin{tabular}{|c|c|c|c|c|c|c|}
\hline & \multicolumn{6}{|c|}{ AUDIT Score } \\
\hline & \multicolumn{3}{|c|}{ Male Flushers } & \multicolumn{3}{|c|}{ Female Flushers } \\
\hline & $\beta^{*}$ & S.E & p-value & $\beta^{*}$ & S.E & p-value \\
\hline \multicolumn{7}{|l|}{ Drinking Motive } \\
\hline Peer Pressure & Ref. & & & & & \\
\hline Pleasure & 2.622 & 0.460 & $<.0001$ & 2.769 & 0.437 & $<.0001$ \\
\hline Stress/Depression & 2.479 & 0.503 & $<.0001$ & 2.489 & 0.475 & $<.0001$ \\
\hline Boredom & -0.261 & 0.607 & 0.667 & 0.469 & 0.551 & 0.394 \\
\hline Other & -0.785 & 1.565 & 0.616 & -2.031 & 1.479 & 0.170 \\
\hline \multicolumn{7}{|l|}{ Year Level } \\
\hline 1 & Ref. & & & Ref. & & \\
\hline 2 & 0.735 & 0.468 & 0.116 & 0.344 & 0.427 & 0.420 \\
\hline 3 & 0.042 & 0.556 & 0.940 & 0.065 & 0.503 & 0.898 \\
\hline$\geq 4$ & -0.425 & 0.526 & 0.419 & -1.587 & 0.508 & 0.002 \\
\hline \multicolumn{7}{|l|}{ Major } \\
\hline Humanities and Social Sciences & Ref. & & & Ref. & & \\
\hline Engineering / Natural Sciences & -0.421 & 0.383 & 0.272 & 0.512 & 0.375 & 0.173 \\
\hline Liberal Arts & 0.341 & 0.692 & 0.622 & -0.472 & 0.509 & 0.354 \\
\hline \multicolumn{7}{|l|}{ GPA } \\
\hline$\geq 4.0$ & Ref. & & & Ref. & & \\
\hline $3.5-4.0$ & -0.121 & 0.555 & 0.827 & 0.014 & 0.519 & 0.978 \\
\hline $3.0-3.5$ & -0.003 & 0.541 & 0.996 & 1.334 & 0.528 & 0.012 \\
\hline$\leq 3.0$ & 1.334 & 0.654 & 0.042 & 0.805 & 0.666 & 0.227 \\
\hline \multicolumn{7}{|l|}{ Pocket Money } \\
\hline Q1 (Low) & Ref. & & & Ref. & & \\
\hline Q2 & 0.485 & 0.473 & 0.305 & 1.161 & 0.429 & 0.007 \\
\hline Q3 & 1.358 & 0.522 & 0.009 & 1.874 & 0.493 & 0.000 \\
\hline Q4 (High) & 1.093 & 0.530 & 0.039 & 2.739 & 0.514 & $<.0001$ \\
\hline \multicolumn{7}{|l|}{ Living Status } \\
\hline Family Home & Ref. & & & Ref. & & \\
\hline Living Alone/Flatting & 0.842 & 0.445 & 0.059 & 1.635 & 0.446 & 0.000 \\
\hline \multicolumn{7}{|l|}{ College Dorm } \\
\hline \multicolumn{7}{|l|}{ Smoking Status } \\
\hline Current Smoker & 1.564 & 0.407 & 0.000 & 1.816 & 0.667 & 0.007 \\
\hline Past Smoker & 1.994 & 0.670 & 0.003 & 5.090 & 1.056 & $<.0001$ \\
\hline Non-Smoker & Ref. & & & Ref. & & \\
\hline \multicolumn{7}{|l|}{ Stress Level } \\
\hline High & 0.463 & 0.736 & 0.529 & -0.876 & 0.685 & 0.201 \\
\hline Normal & 0.227 & 0.464 & 0.625 & 0.110 & 0.494 & 0.824 \\
\hline Low & Ref. & & & Ref. & & \\
\hline \multicolumn{7}{|l|}{ Depressive Thoughts } \\
\hline Yes & 0.521 & 0.646 & 0.419 & 0.347 & 0.524 & 0.508 \\
\hline No & Ref. & & & Ref. & & \\
\hline \multicolumn{7}{|l|}{ Suicidal Thoughts } \\
\hline Yes & 1.632 & 1.236 & 0.186 & 0.164 & 1.026 & 0.873 \\
\hline No & Ref. & & & Ref. & & \\
\hline \multicolumn{7}{|l|}{ Suicidal Attempt } \\
\hline Yes & 6.057 & 1.700 & 0.000 & 3.241 & 1.495 & 0.030 \\
\hline No & Ref. & & & Ref. & & \\
\hline \multicolumn{7}{|l|}{ Underage Drinking Experience } \\
\hline Yes & 0.645 & 0.378 & 0.088 & 0.714 & 0.351 & 0.042 \\
\hline No & Ref. & & & Ref. & & \\
\hline \multicolumn{7}{|l|}{ Number of sororities/clubs } \\
\hline None & Ref. & & & Ref. & & \\
\hline One & 0.460 & 0.392 & 0.240 & 0.255 & 0.369 & 0.489 \\
\hline Two or more & 1.383 & 0.637 & 0.030 & 1.156 & 0.594 & 0.052 \\
\hline
\end{tabular}


Male

AUDIT by Facial Flushing Status

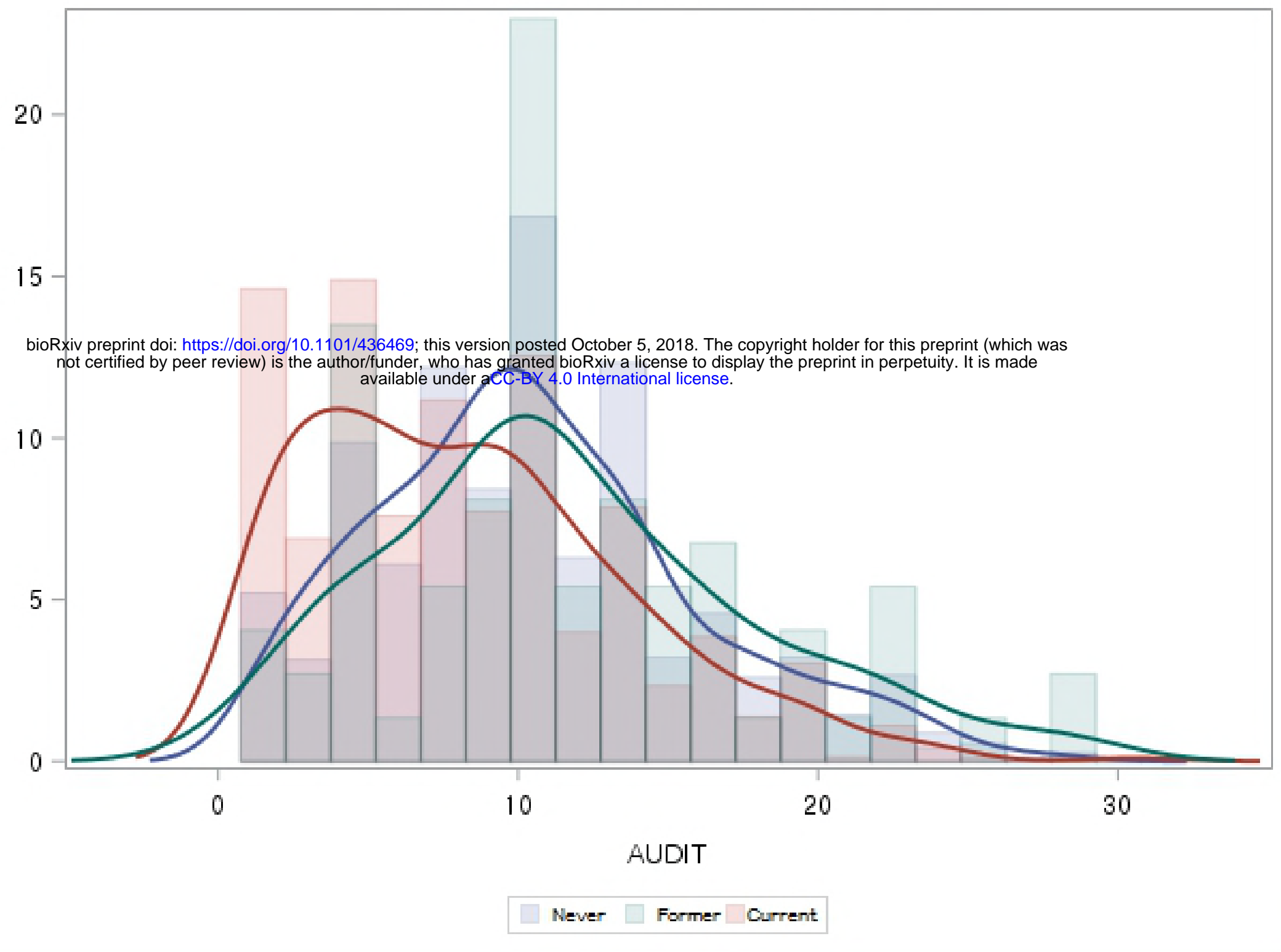

\section{Female}

\section{AUDIT by Facial Flushing Status}

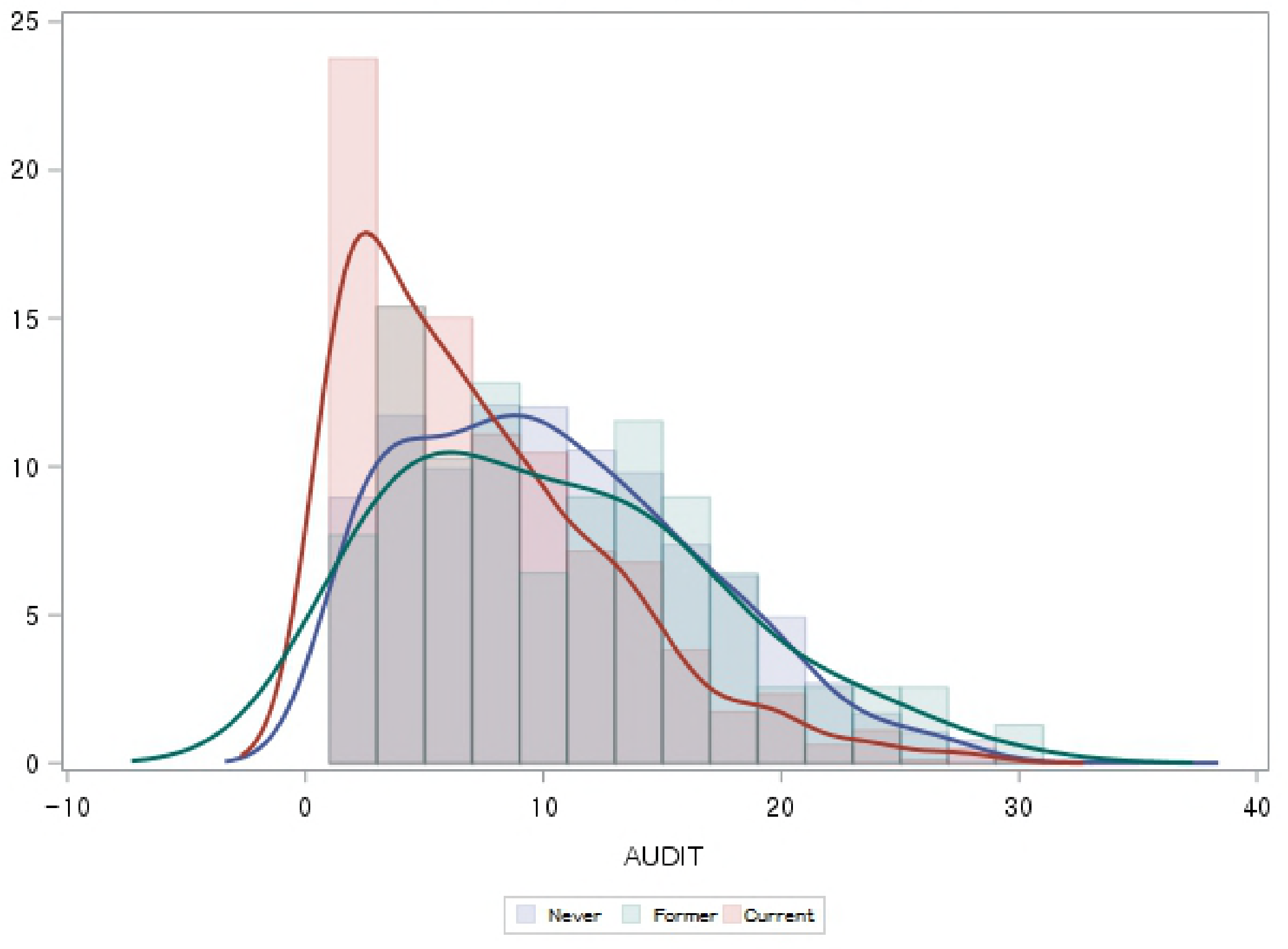



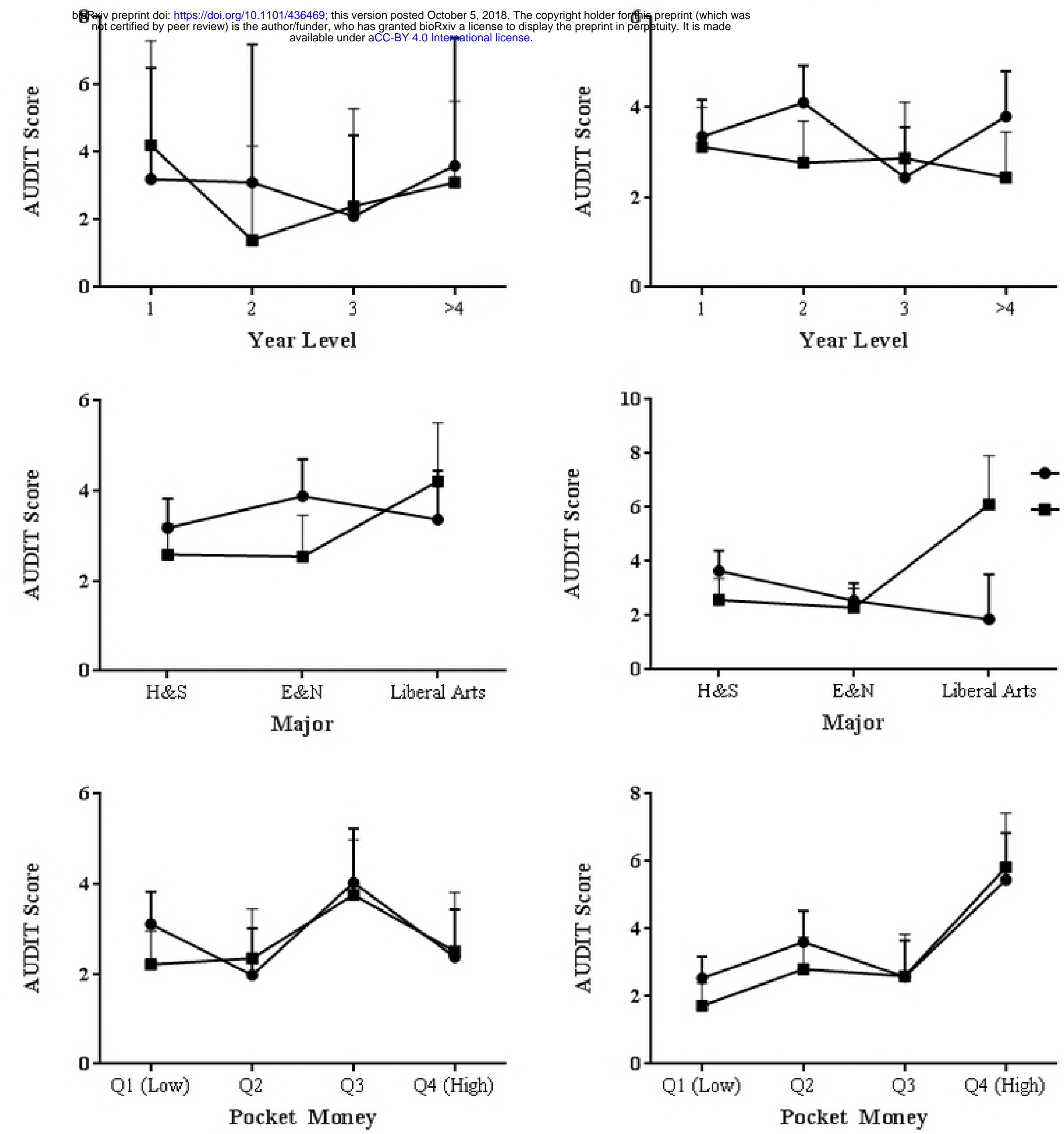